\title{
Forum
}

\section{Saltcedar Water Use: Realistic and Unrealistic Expectations}

\author{
M. Keith Owens ${ }^{1}$ and Georgianne W. Moore ${ }^{2}$ \\ Authors are ${ }^{1}$ Professor and Head, Department of Natural Resource Ecology \& Management, Oklahoma State University, Stillwater, OK 74078; \\ and ${ }^{2}$ Assistant Professor, Department of Rangeland Ecology \& Management, Texas A\&M University, College Station, TX 77843.
}

\begin{abstract}
Saltcedar (Tamarix spp.) is a widespread invasive plant found in riparian corridors and floodplains in 16 western states. In addition to being associated with such problems as increased soil salinity and decreased plant diversity, saltcedar has been reported to be a prolific water user. Popular press articles widely report that each individual saltcedar tree can use as much as 757 L (200 gallons) per day. Consequently massive control and removal efforts are underway to reduce transpirational water loss and increase water salvage for arid and semiarid environments. Although the potential economic benefits of these control efforts are touted, it has not been proven whether such water savings are possible on a stream level. The original citation for the 757-L estimate does not list the experimental design or techniques used to arrive at this value. We use three lines of evidencepeer-reviewed scientific literature, sap flux rates and sap wood area, and potential evaporation rates-to demonstrate the improbability that saltcedar, or any other woody species, can use this much water per tree on a daily basis. A more realistic estimate of maximum tree-level daily water use derived from sap flux measurements would be $<122 \mathrm{~L} \cdot \mathrm{d}^{-1}$ (32.2 gallons). Estimates of water salvage would be grossly overestimated using the popular water use value $\left(757 \mathrm{~L} \cdot \mathrm{d}^{-1}\right)$, and economic benefits from saltcedar control based solely on water salvage are questionable.
\end{abstract}

\section{Resumen}

"Saltcedar" (Tamarix spp.) es una especie invasora ampliamente distribuida en los corredores y vegas de los ríos de los 16 estados del oeste. Además de ser asociada a problemas como aumento en la salinidad del suelo y reducción de la diversidad vegetal, se ha reportado que el "Saltcedar" es un gran consumidor de agua. Los artículos de la prensa popular reportan ampliamente que cada árbol de "Saltcedar" puede usar hasta 757 L (200 galones) de agua por día. Consecuentemente, los esfuerzos de control y remoción masiva son dirigidos a reducir las pérdidas de agua por transpiración e incrementar el ahorro de agua en los ambientes áridos y semiáridos. Aunque los beneficios económicos potenciales de estos esfuerzos de control son pregonados, no han sido probado si tales ahorros de agua son posibles a nivel de corrientes de agua. La cita original de la estimación de 757 L no enlista el diseño experimental o las técnicas usadas para llegar a este valor. Nosotros usamos tres líneas de evidencia (artículos científicos arbitrados, tasas de flujo de savia y área de madera de savia y tasas de evaporación potencial) para demostrar que es improbable que el "Saltcedar," o cualquier otra especie leñosa, puede usar esta cantidad por árbol por día. Una estimación más real del uso diario máximo de agua a nivel de árbol, derivado de las mediciones de flujo de savia, sería $<122 \mathrm{~L} \cdot \mathrm{d}^{-1}$ (32.2 galones). Usando el valor popular $\left(757 \mathrm{~L} \cdot \mathrm{d}^{-1}\right.$ ) las estimaciones de ahorro de agua pudieran ser enormemente sobreestimadas y los beneficios económicos del control de "Saltcedar," basados solamente en el ahorro de agua, son cuestionables.

Key Words: rangeland hydrology, semiarid, tamarisk, transpiration, water yield

\section{INTRODUCTION}

Water is the most limiting resource in semiarid and arid environments. Native vegetation, irrigated agriculture, and municipal growth depend on the production of water from rangelands and on the conservation of water from rivers and aquifers. Brush (or woody plant) control has been promoted as a means to increase water production from rangelands, although the net gain is not always predictable (Wilcox 2002; Wilcox and

This material is based upon work supported by the Cooperative State Research, Education and Extension Service, U.S. Department of Agriculture under Agreement No. 2005-34461-15661.

At the time of research, Owens was Professor, Texas Agricultural Experiment Station, Uvalde, TX.

Correspondence: M. Keith Owens, 008C Agricultural Hall, Oklahoma State University, Stillwater, OK 74078. Email: keith.owens@okstate.edu

Manuscript received 23 February 2007; manuscript accepted 7 June 2007.
Thurow 2006). A recent review of how woody plant manipulation may affect stream flow concluded that potential water salvage was dependent on specific attributes of climate, soils, and physiography (Wilcox et al. 2006). The most likely conditions for water savings are when woody plants are removed from a riparian zone with direct access to groundwater (Wilcox et al. 2006).

Saltcedar (Tamarix spp.) was originally introduced to the southwestern United States in the late 1800s as an ornamental for landscaping and for bank stabilization (Shafroth et al. 2005), but it has now effectively spread along riparian corridors throughout the western United States. The impacts of saltcedar on local and regional hydrologic budgets have long been a concern (Gatewood et al. 1950; Blaney and Hanson 1965; Gay and Fritschen 1979; Weeks et al. 1987). None of these studies of saltcedar removal have demonstrated a basinlevel response in river flow; however, many smaller-scale studies have concluded that water savings could be huge 
(summarized in Wilcox et al. 2006). Hays (2003) summarizes the results from 13 papers that studied water use from saltcedar communities. The units used in each report vary, but if we assume a $180 \mathrm{~d}$ growing season, then water use ranged between 1.6 and $16.3 \mathrm{~mm} \cdot \mathrm{d}^{-1}\left(\right.$ mean $\left.=7.9 \mathrm{~mm} \cdot \mathrm{d}^{-1}, \mathrm{SE}=1.04\right)$. These values are equal to, and sometimes in excess of, water use for other riparian woody vegetation. Cleverly et al. (2002) also report results from 18 studies of saltcedar where daily transpiration is between 0 and $20 \mathrm{~mm} \cdot \mathrm{d}^{-1}$, which is within the range of water use reported for native woody plants (Scott et al. 2004; Nagler et al. 2005a; Nagler et al. 2005b).

Saltcedar has been reported to use 200 gallons of water per tree each day $(757 \mathrm{~L})$, and this number has been the basis for much discussion and legislation. Extension publications from North Dakota to Arizona, a coloring book teaching children about the plant, and a legislative resolution in Colorado (HJR 03-1048) perpetuate this water use figure. A thorough literature search, however, could not reveal the original manuscript with the experimental methods that derived this number. Most citations refer to Holdenbach (1987), although that manuscript does not report the techniques used to estimate water use and simply states that saltcedar uses this much water. The amount of water this tree uses is of critical importance in predicting water salvage from control efforts. A recent bill in the 109th Congress (H.R. 2720; www.tamariskcoalition.org/ TamariskCoalition//Downloads/CongressionalLegislation.pdf; accessed 30 March 2007) authorized the "Salt Cedar and Russian Olive Control Demonstration Act" to investigate and demonstrate how saltcedar control can affect hydrologic and ecologic function.

We use three lines of investigation to determine if woody vegetation in general, and of saltcedar in particular, could transpire the reported $757 \mathrm{~L}$ on a daily basis. The purpose of this investigation is to provide an upper bound for maximum daily water consumption for individual saltcedar trees. The first line of investigation is a literature review of woody plant water use published in peer-reviewed journals. The second line uses sap flux measures from our studies and from published literature, combined with sap wood areas measured in mature and in young, dense saltcedar stands, to estimate daily water use. The third line calculates potential water lost from pan evaporation in areas where saltcedar grows and compares that to the reported water use.

\section{LITERATURE REVIEW OF WOODY PLANT WATER USE}

An examination of peer-reviewed literature revealed 125 estimates of water use by woody plants that reported either the volume or mass of water transpired daily. A particularly thorough report on 92 combinations of plant species and environments, including desert shrubs, desert trees, riparian trees, and tropical trees, was found in Wullschleger et al. (1998, Table 1). In addition, 34 other woody species were used to determine potential water loss (see Table 1 for citations). Water use estimates in these reports were made using Bowen ratio, eddy covariance, lysimeter, and sap flux techniques. Each of these techniques has a specific set of assumptions that are reported in the original citations. However, because all these water use estimates are in peer-reviewed literature, we will assume that in each case data accuracy was verified.

Mean water use of saltcedar trees has been reported in relatively few studies, and most of the studies have been of short duration $(<14$ days) and focused on small stems. The seven published studies on saltcedar water use reported a range of $0.4-56.8 \mathrm{~L} \cdot \mathrm{d}^{-1} \cdot \operatorname{tree}^{-1}$ (Table 1; Fig. 1). This wide range reflects different trees sizes and leaf areas in the various studies. Unpublished data from recent studies on the Pecos River in Texas and the middle Rio Grande in New Mexico suggest that average water use of mature trees was $29.9 \mathrm{~L} \cdot \mathrm{d}^{-1}$ (G. W. Moore and M. K. Owens, unpublished data, 2005).

Mean water use of all woody plants was $117.5 \mathrm{~L} \cdot \mathrm{d}^{-1}$, and the standard deviation was \pm 148.6 (Fig. 1). Most of the values above $284 \mathrm{~L} \cdot \mathrm{d}^{-1}$ are from tropical rainforest trees, and each tree had more than $500 \mathrm{~cm}^{2}$ of sapwood area (see the next section for saltcedar sapwood areas). The most extreme value reported in Wullschleger et al. (1998) was $1180 \mathrm{~L} \cdot \mathrm{d}^{-1}$ for a rainforest tree species with over $1500 \mathrm{~cm}^{2}$ sapwood area (data point not included in the figure). Assuming a normal distribution, a standard practice recommended in most statistical textbooks is to consider any observations greater than the mean \pm 3 times the standard deviation as an outlier that can be dropped from the analysis (Neter and Wasserman 1974, p. 106). At the very least, these outliers should be viewed with skepticism and verified through other means. Figure 1 shows that the daily water use of $757 \mathrm{~L} \cdot \mathrm{d}^{-1}$ for saltcedar is clearly a statistical outlier. Alternatively, if the data are not normally distributed then a potential outlier is identified as

$$
\text { ExtremeOutlier }>Q 3+3(Q 3-Q 1) \text {, }
$$

where $Q 3=75 \%$ quartile and $Q 1=25 \%$ quartile. In this case, where $Q 3=150$ and $Q 1=27$, an extreme outlier would be greater than $519 \mathrm{~L} \cdot \mathrm{d}^{-1}$. The reported value of $757 \mathrm{~L} \cdot \mathrm{d}^{-1}$ is clearly greater than the upper limit for either a normal or a nonnormal distribution. This line of evidence suggests that the reported value of water use for saltcedar is a statistical outlier, and that this value is almost certainly incorrect and should not be used.

\section{SAP FLUX RATES AND SAP WOOD AREA}

Sap flux is the amount of water flowing inside the plant at any given time. Because it integrates water loss over the entire canopy, it is a direct estimate of transpirational water loss. It can be measured with a variety of techniques including heat dissipation (Granier 1987), heat pulse (Kluitenberg and Ham 2004), and heat balance (Kjelgaard et al. 1997). In all cases the sensors are either inserted into the xylem or wrapped around small branches and then electronically monitored on a continuous basis. The sap flux per unit sapwood area or leaf area is then multiplied by the whole-tree sapwood area or leaf area to estimate total transpirational flow within the plant.

We monitored sap flux of saltcedar trees at five locations on the middle Rio Grande and one location on the Pecos River in 2004 and at two locations on the Pecos River in 2005 and 2006 using a heat dissipation technique. During that period, 
Table 1. Plant species, stand age, sapwood area, and plant water use from woody plants in different environments.

\begin{tabular}{|c|c|c|c|c|c|}
\hline Species & & $\operatorname{Age}^{1}(y r)$ & Sapwood area $\left(\mathrm{cm}^{2}\right)$ & Water use $\left(L \cdot d^{-1}\right)$ & Source \\
\hline Arrowweed & Pluchea sericea (Nutt.) Colville & & 10 & 1.1 & Sala et al. 1996 \\
\hline Ashe juniper & Juniperus ashei Buchh. & $>20$ & & 124.9 & Owens 1996 \\
\hline Black gum & Nyssa sylvatica March. & 75 & 493 & 82 & Wullschleger et al. 2001 \\
\hline Chestnut oak & Quercus prinus $\mathrm{L}$. & 50 & 600 & 143.8 & Wullschleger et al. 2001 \\
\hline \multirow[t]{3}{*}{ Fremont cottonwood } & Populus fremontii S. Wats. & 1 & 33 & 57.6 & Nagler et al. 2003 \\
\hline & & & 833 & 499.7 & Schaeffer et al. 2000 \\
\hline & & 5 & & 135.8 & Nagler et al. 2007 \\
\hline \multirow[t]{2}{*}{ Douglas fir } & Pseudotsuga menziesii (Mirbel) & 40 & 30 & 52.6 & Moore et al. 2004 \\
\hline & Franco & 450 & 2200 & 198.0 & Moore et al. 2004 \\
\hline \multirow[t]{2}{*}{ Goodding's willow } & Salix gooddingii Ball. & 1 & 3.1 & 53.0 & Nagler et al. 2003 \\
\hline & & & 196 & 98.4 & Schaeffer et al. 2000 \\
\hline Live oak & Quercus virginiana P. Mill. & $>20$ & & 71.9 & Owens 1996 \\
\hline Loblolly pine & Pinus taeda $\mathrm{L}$. & $<13$ & 40 & 6.4 & Phillips et al. 1996 \\
\hline \multirow[t]{2}{*}{ Mountain ash } & Eucalyptus regnans F.J. Muell. & 56 & 618 & 280.1 & Vertessy et al. 1997 \\
\hline & & 15 & 451 & 150.6 & Vertessy et al. 1995 \\
\hline Narrowleaf willow & Salix exigua Nutt. & & 10 & 3.0 & Sala et al.1996 \\
\hline Pacific silver fir & $\begin{array}{l}\text { Abies amabilis (Dougl. ex Loud.) } \\
\text { Dougl. ex Forbes }\end{array}$ & 43 & & 98.0 & Martin et al. 1997 \\
\hline Red alder & Alnus rubra Bong. & 40 & 700 & 104.9 & Moore et al. 2004 \\
\hline Red maple & Acer rubrum $\mathrm{L}$. & 75 & 742 & 153 & Wullschleger et al. 2001 \\
\hline Red oak & Quercus rubra L. & 75 & 242 & 46 & Wullschleger et al. 2001 \\
\hline \multirow[t]{8}{*}{ Saltcedar } & Tamarix spp. & & 10 & 6.1 & Sala et al. 1996 \\
\hline & & & 10 & 15.9 & Smith et al. 1996 \\
\hline & & 1 & 33 & 56.8 & Nagler et al. 2003 \\
\hline & & $>15$ & 100 & 29.9 & $\begin{array}{l}\text { G. W. Moore and M. K. Owens, } \\
\text { unpublished data, } 2006\end{array}$ \\
\hline & & & & 757.1 & Unknown \\
\hline & & & 0.49 & 0.4 & Cleverly et al. 1997 \\
\hline & & & 0.49 & 0.8 & Devitt et al. 1997 \\
\hline & & & & 5.6 & Davenport et al. 1982 \\
\hline Screwbean mesquite & Prosopis pubescens Benth. & & 10 & 4.5 & Sala et al. 1996 \\
\hline Silver wattle & Acacia frigescens J.H. Willis & 15 & 278.5 & 58.9 & Vertessey et al. 1995 \\
\hline Sweet gum & Liquidambar styraciflua L. & $<13$ & 50 & 15.1 & Phillips et al. 1996 \\
\hline Western hemlock & Tsuga heterophylla (Raf.) Sarg. & 450 & 190 & 85.6 & Moore et al. 2004 \\
\hline White oak & Quercus alba L. & 75 & 395 & 71 & Wullschleger et al. 2001. \\
\hline Yellow poplar & Liriodendron tulipifera L. & 75 & 417 & 63 & Wullschleger et al. 2001 \\
\hline
\end{tabular}

${ }^{1}$ Blank cells signify that the original manuscript did not contain the needed data.

maximum sapflow in mature saltcedar stands was $4399 \mathrm{~mm} \cdot \mathrm{m}^{-2}$ sapwood area $\cdot \mathrm{d}^{-1}$, and the mean during the growing season was $1835 \mathrm{~mm} \cdot \mathrm{m}^{-2}$ sapwood area $\cdot \mathrm{d}^{-1}$. These values convert to $4399 \mathrm{~L}$ and $1835 \mathrm{~L} \mathrm{~d}^{-1}$ for each square meter of sapwood area.

Most saltcedar trees are multistemmed, so tree-level sapwood area is the sum of all the individual stems. We sampled areas in a dense, young monoculture on the middle Rio Grande and in a mature stand on the Pecos River. Plots were delineated (a single $10 \times 10 \mathrm{~m}$ plot on the Rio Grande and a single $14 \times 17 \mathrm{~m}$ plot on the Pecos River), and all trees within the plot were cut down within $20 \mathrm{~cm}$ of the ground surface for detailed sapwood area analysis. A single plot was used at each site. Digital photographs were taken of every cut stump, sapwood cross-sectional areas were delineated, and sapwood area per tree and per plot was calculated. Most stems had $<50 \mathrm{~cm}^{2}$ sapwood area, and most trees had fewer than eight stems. The largest tree had $246 \mathrm{~cm}^{2}$ sapwood area distributed across seven stems. When considering just the largest tree during the maximum sap flux period, the tree could transpire $121.4 \mathrm{~L}$ of water over the course of the day. On an average day, the tree would transpire $52.5 \mathrm{~L}$ of water. In the mature saltcedar stand (Pecos River site), the entire plot of $238 \mathrm{~m}^{2}$ yielded $1626 \mathrm{~cm}^{2}$ sapwood area, which would result in water loss of $555 \mathrm{~L}$ on the maximum day and 61.2 $\mathrm{L}$ on an average day for the given area containing a total of 61 trees. The young monoculture plot (Rio Grande River) had the greatest sapwood area $\left(3125 \mathrm{~cm}^{2}\right.$ in a $100 \mathrm{~m}^{2}$ ground area). Water loss in the entire area that contained 107 trees would be $1375 \mathrm{~L}$ on the maximum flow day, and $573 \mathrm{~L}$ on an average day.

The amount of reported water use by saltcedar $\left(757 \mathrm{~L} \cdot \mathrm{d}^{-1}\right)$ is clearly much greater than measured water use by single trees 


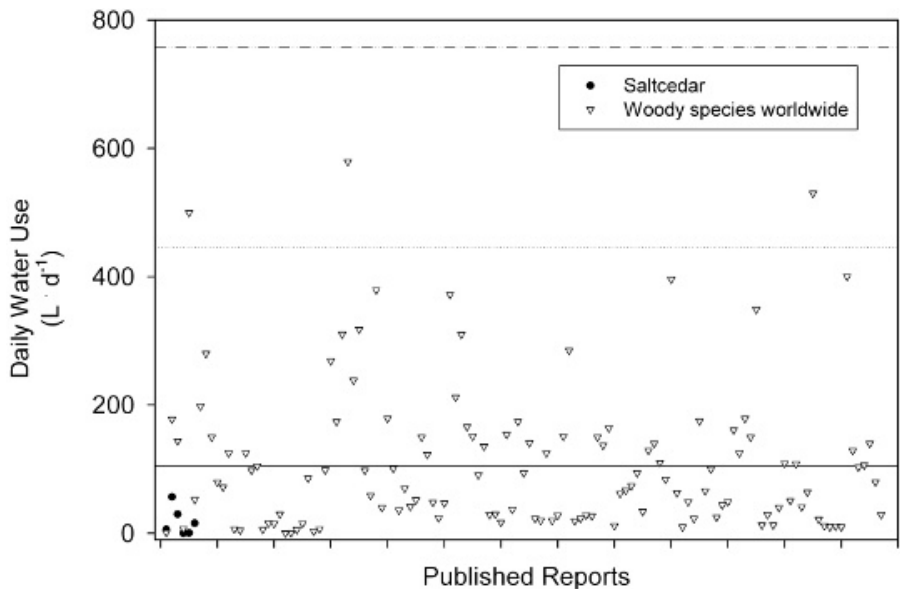

Figure 1. Daily plant water use for woody plants reported in the peerreviewed literature. The solid line represents the mean, the dotted line represents 3 times the standard deviation, and the dashed line represents the amount of water use attributed to saltcedar.

on either the Pecos or Rio Grande rivers. In fact, calculated water use from large plots could not equal the reported value for a single tree on an average day. This second line of evidence also suggests that the often-cited value of $757 \mathrm{~L} \cdot \mathrm{d}^{-1}$ is a gross overestimation.

\section{POTENTIAL PAN EVAPORATION}

Plants are not pumps and must conduct water in accordance with atmospheric demand, leaf area, and internal limitations. If a tree can use $757 \mathrm{~L}$ of water each day, then the atmospheric demand must be great, internal limitations must be small, and/ or the total leaf area must be large. In this line of evidence, we calculate potential pan evaporation from an area equal to the average-sized saltcedar tree, adjust this value with published pan coefficients to estimate potential evapotranspiration, and determine the crop coefficient $\left(k_{c}\right)$ required to reconcile the potential evapotranspiration with the reported actual evapotranspiration. The $k_{c}$ value is compared to published values for crops and trees from an FAO publication (Allen et al. 1998).

Atmospheric demand can be best represented by pan evaporation. Pan evaporation poses no resistance to evaporation, whereas transpiration in plants is limited by resistances at the leaf boundary layer, stomata, stems, and roots. These resistances are additive and can greatly reduce the potential for evaporation per unit leaf area compared to an open pan of water. Pan evaporation represents an index of potential evapotranspiration (PET), but pan evaporation can be greater than actual evaporation from large bodies of water because of pan heating and air turbulence (Allen et al. 1998). A pan coefficient must be used to reduce the observed pan evaporation rates and remove the effects of the pan. Actual evapotranspiration rates (AETs) are typically lower than potential rates (PETs) early in the growing season and may be greater than $P E T$ s later in the season as leaf area increases. For example, AETs in a well-irrigated corn crop vary throughout the growing season, ranging between 30\% PET after planting to a maximum of $120 \%$ PET when leaf area peaks in the midseason (Allen et al. 1998). The AETs are related to pan evaporation using the following equation:

$$
A E T=P_{e} \cdot P_{c} \cdot k_{c},
$$

where $P_{e}=$ pan evaporation, $P_{c}=$ pan coefficient, and $k_{c}=$ crop coefficient. We can rearrange equation [1] to calculate the $k_{c}$ as

$$
k_{c}=\operatorname{AET} /\left(P_{e} \cdot P_{c}\right)
$$

Saltcedar in the southwestern United States grows mainly in the $254-308 \mathrm{~cm} \cdot \mathrm{y}^{-1}$ pan evaporation zones (http://www.grow. arizona.edu/images/water/panevap.gif; accessed 12 December 2006). The average canopy diameter of mature saltcedar trees on the Pecos River was $6.0 \mathrm{~m}$ (M. K. Owens and G. W. Moore, unpublished data, 2006). If we consider a ground surface area of $6 \mathrm{~m}$ diameter $\left(28.27 \mathrm{~m}^{2}\right)$ and compress all annual evaporation to within the $200 \mathrm{~d}$ growing season (the most stringent test for plant water use), then pan evaporation would be between 270 and $323 \mathrm{~L} \cdot \mathrm{d}^{-1}$. We will use the highest possible evaporation $\left(323 \mathrm{~L} \cdot \mathrm{d}^{-1}\right)$ for the remainder of the calculations. In areas with low humidity and moderate winds, the pan coefficient is about 0.75 (Allen et al. 1998, table 5). By substituting these values $\left(P_{e}=323, P_{c}=0.75\right.$, and $A E T=757)$ into equation [3], the crop coefficient would have to be 2.34 in order to reach the reported water loss of $757 \mathrm{~L} \cdot \mathrm{d}^{-1}$. Crop coefficients published in the FAO publication (Allen et al. 1998, table 12) range from 0.3 in early crops to 1.4 in dense agronomic crops, and from 0.65 to 1.15 for a variety of trees. The required crop coefficient is clearly greater than other published coefficients for agronomic and woody plants. This third line of evidence also suggests that saltcedar trees cannot use $757 \mathrm{~L} \cdot \mathrm{d}^{-1}$.

\section{MANAGEMENT IMPLICATIONS}

Three lines of evidence-an examination of peer-reviewed journal articles, a calculation of published sap flux rates and sapwood area, and calculation of crop coefficients using potential versus actual evapotranspiration-have demonstrated that it is extremely unlikely that individual saltcedar trees can use the $757 \mathrm{~L} \cdot \mathrm{d}^{-1}$ often reported in the popular literature. These three lines of evidence were collected independently, and all support the idea that actual water use would be much less. In fact, water use based on a limited sample of sapwood area on the Rio Grande and Pecos rivers and detailed sap flux estimates would be $<122 \mathrm{~L} \cdot \mathrm{d}^{-1}$. Because of the small sample size of sapwood area, we suggest that this estimate of saltcedar water use needs further refinement. Like all other trees, including natives endemic to the region affected by saltcedar, maximum water use in saltcedar is limited by physical characteristics of size, leaf area, and local environmental conditions. It may be highly desirable to control saltcedar for reasons such as wildlife habitat, biological diversity, soil health, or salinity control (see Shafroth et al. 2005), but predicting water salvage based on 
a reported daily water use of $757 \mathrm{~L} \cdot \mathrm{d}^{-1}$ will drastically overestimate potential gains.

\section{LITERATURE CITED}

Allen, R. G., L. S. Pereira, D. Raes, and M. Smith. 1998. Crop evapotranspiration: guidelines for computing crop water requirements. Rome, Italy: Food and Agriculture Organization of the United Nations. 299 p.

Blaney, H. F., and E. G. Hanson. 1965. Consumptive use and water requirements in New Mexico. Santa Fe, NM: New Mexico State Engineer. 88 p.

Cleverly, J. R., C. N. Dahm, J. R. Thibault, D. J. Gilroy, and J. E. A. Coonrod. 2002. Seasonal estimates of actual evapo-transpiration from Tamarix ramossima stands using three-dimensional eddy covariance. Journal of Arid Environments 52:181-197.

Cleverly, J. R., S. D. Smith, A. Sala, and D. A. Devitt. 1997. Invasive capacity of Tamarix ramossima in a Mojave Desert floodplain: the role of drought. Oecologia 111:12-18.

Davenport, D. C., P. A. Martin, and R. M. Hagen. 1982. Evapotranspiration from riparian vegetation: water relations and irrecoverable losses for saltcedar. Journal of Soil and Water Conservation 37:233-236.

Devitt, D. A., J. M. Piorkowski, S. D. Smith, J. R. Cleverly, and A. Sala. 1997. Plant water relations of Tamarix ramossima in response to the imposition and alleviation of soil moisture stress. Journal of Arid Environments 36:527-540.

Gatewood, J. S., T. W. Robinson, B. R. Colby, J. D. Hem, and L. C. Halpenny. 1950. Use of water by bottom-land vegetation in lower Safford Valley, Arizona. Ecological survey water supply paper 1103. Washington, DC: US Geological Survey. $210 \mathrm{p}$.

Gay, L. W., AND L. J. Fritschen. 1979. An energy budget analysis of water use by saltcedar. Water Resources Research 15(6):1589-1592.

Granier, A. 1987. Evaluation of transpiration in a Douglas-fir stand by means of sap flow measurements. Tree Physiology 3:309-320.

HaYs, B. 2003. Water use by saltcedar (Tamarix sp.) and associated vegetation on the Canadian, Colorado and Pecos rivers in Texas [MS thesis]. College Station, TX: Texas A\&M University. $116 p$.

HoldenBaCH, G. 1987. Tamarix control. In: M. R. Kunzmann, R. R. Johnson, and P. Bennett [EDS.]. Tamarix control in the United States. Tucson, AZ: University of Arizona. p. 116-123.

Kuelgaard, J. F., C. O. Stockle, R. A. Black, and G. S. Campbell. 1997. Measuring sap flow with the heat balance approach using constant and variable heat inputs. Agricultural and Forest Meteorology 85(3-4):239-250.

Kluitenberg, G. J., AND J. M. Ham. 2004. Improved theory for calculating sap flow with the heat pulse method. Agricultural and Forest Meteorology 126:169-173.

Martin, T. A., K. J. Brown, J. Cermak, R. Ceulemans, J. Kucera, F. C. Meinzer, J. S. Rombold, D. G. Sprugel, and T. M. Hinckley. 1997. Crown conductance and tree and stand transpiration in a second-growth Abies amabilis forest. Canadian Journal of Forest Research 27:797-808.

Moore, G. W., B. J. Bond, J. A. Jones, N. Phillips, and F. C. Meinzer. 2004. Structural and compositional controls for transpiration between 40- and 450-yr-old forests in Western Oregon, USA. Tree Physiology 24(5):481-491.

Nagler, P. L., J. Cleverly, E. Glenn, D. Lampkin, A. Huete, and Z. Wan. $2005 a$. Predicting riparian evapotranspiration from MODIS vegetation indices and meteorological data. Remote Sensing of Environment 94(1):17-30.

Nagler, P. L., E. P. Glenn, and T. L. Thompson. 2003. Comparison of transpiration rates among saltcedar, cottonwood and willow trees by sap flow and canopy temperature models. Agricultural and Forest Meteorology 116:73-89.
Nagler, P., A. Jetton, J. Fleming, K. Didan, E. Glenn, J. Erker, K. Morino, J. Milliken, AND S. GLoss. 2007. Evapotranspiration in a cottonwood (Populus fremontii) restoration plantation estimated by sap flow and remote sensing methods. Agricultural and Forest Meteorology 144(1-2):95-110.

Nagler, P. L., R. L. Scott, C. Westenburg, J. R. Cleverly, E. P. Glenn, and A. R. Huete. 2005b. Evapotranspiration on western U.S. rivers estimated using the Enhanced Vegetation Index from MODIS and data from eddy covariance and Bowen ratio flux towers. Remote Sensing of Environment 97(3):337-351.

Neter, J., And W. Wasserman. 1974. Applied linear statistical models. Homewood, IL: Richard D. Irwin. $842 \mathrm{p}$.

Owens, M. K. 1996. The role of leaf and canopy-level gas exchange in the replacement of Quercus virginiana (Fagaceae) by Juniperus ashei (Cupressaceae) in semiarid savannas. American Journal of Botany 83(5):617-623.

Phillips, N., R. Oren, and R. Zimmermann. 1996. Radial patterns of xylem sap flow in non-, diffuse-, and ring-porous tree species. Plant, Cell, and Environment 19:983-990.

Sala, A., S. D. Smith, and D. A. Devitt. 1996. Water use by Tamarix ramosissima and associated phreatophytes in a mojave desert floodplain. Ecological Applications 6(3):888-898.

Schaeffer, S. M., D. G. Williams, and D. C. Goodrich. 2000. Transpiration of cottonwood/willow forest estimated from sap flux. Agricultural and Forest Meteorology 105(1-3):257-270.

Scott, R. L., E. A. Edwards, W. J. Shuttleworth, T. E. Huxman, C. Watts, and D. C. GoodRICH. 2004. Interannual and seasonal variation in fluxes of water and carbon dioxide from a riparian woodland ecosystem. Agricultural and Forest Meteorology 122(1-2):65-84.

Shafroth, P. B., J. R. Cleverly, T. L. Dudley, J. P. Taylor, C. Van Riper, E. P. Weeks, and J. N. Stuart. 2005. Control of Tamarix in the Western United States: implications for water salvage, wildlife use, and riparian restoration. Environmental Management 35(3):231-246.

Smith, S. D., A. Sala, D. A. Devitt, and J. Cleverly. 1996. Evapotranspiration from a saltcedar-dominated desert floodplain: a scaling approach. In: J. R. Barrow, E. D. McArthur, R. E. Sosebee, and R. J. Tausch [EDS.]. Shrubland ecosystem dynamics in a changing environment. Las Cruces, NM: USDA Forest Service. p. 199-204.

Vertessey, R. A., R. G. Benyon, S. K. O'Sullivan, and P. R. Gribben. 1995. Relationships between stem diameter, sapwood area, leaf area and transpiration in a young mountain ash forest. Tree Physiology 15:559-567.

Vertessy, R. A., T. J. Hatton, P. Reece, S. K. O'Sullivan, and R. G. Benyon. 1997. Estimating stand water use of large mountain ash trees and validation of the sap flow measurement technique. Tree Physiology 17:747-756.

Weeks, E. P., H. L. Weaver, G. S. Campbell, and B. D. Tanner. 1987. Water use by saltcedar and by replacement vegetation in the Pecos River floodplain between Acme and Artesia, New Mexico. USGS professional paper 491-G. Washington, DC: US Geological Survey. 33 p.

WILcox, B. P. 2002. Shrub control and streamflow on rangelands: a process-based viewpoint. Journal of Range Management 55:318-326.

Wilcox, B. P., M. K. Owens, W. A. Dugas, D. N. Ueckert, and C. R. Hart. 2006. Shrubs, streamflow, and the paradox of scale. Hydrological Processes 20:3245-3259.

WILCOX, B. P., AND T. L. ThuRow. 2006. Emerging issues in rangeland ecohydrology: vegetation change and the water cycle. Rangeland Ecology \& Management 59(6):220-224.

Wullschleger, S. D., P. J. Hanson, and D. E. Todd. 2001. Transpiration from a multispecies deciduous forest as estimated by xylem sap flow techniques. Forest Ecology and Management 143:205-213.

Wullschleger, S. D., F. C. Meinzer, and R. A. Vertessy. 1998. A review of wholeplant water use studies in trees. Tree Physiology 18:499-512. 